\title{
ACCOUNTING POLICIES AND PROCEDURES IN THE PREPARATION OF THE ANNUAL REPORT
}

\author{
Ave Nukka \\ Lääne-Viru College, Estonia \\ Malle Kasearu \\ Lääne-Viru College, Estonia
}

\begin{abstract}
In accordance with Para 14 in the Estonian Accounting Act (AA) all accounting entities are compelled to prepare the annual report for the year ended, which consists of the financial statements and the management report. To ensure that the prepared annual report would meet its purpose the legislative requirements have to be followed and any peculiarities arising from an accounting entity's field of activity should be regulated in the entity's accounting policies and procedures. The objective of the given article is to give an overview about activities required for the preparation of the annual report, alternative accounting policies and accounting estimates, and their presentation in the internal regulations based on companies used as internship bases. The results of the survey revealed that the accounting policies were disclosed according to the rules in the majority of larger internship companies. Inventory taking procedure was established by the internal accounting regulations and implemented in practice in $83 \%$ of the companies/organisations that participated in the survey.

Based on the results of the survey we may conclude that medium-sized and large enterprises are more likely to be accurate while establishing internal regulations and the related documentation. Micro- and small enterprises showed more deficiencies in working out their internal regulations as well as in the details to which the given rules were followed. The investigation of the documents revealed that the activities required to prepare the annual report are performed in companies and this provides a prerequisite for the annual report to give a true and fair view.
\end{abstract}

Keywords: annual report, accounting policies, internal accounting regulations, inventory, accounting estimates

JEL code: M41

\section{Introduction and methodology}

In accordance with Para 14 in the Estonian Accounting Act (AA) all accounting entities are compelled to prepare the annual report for the year ended, which consists of the financial statements and the management report. The purpose of the preparation and disclosure of the annual report is to give the users relevant and faithfully presented information about the accounting entity's financial position, economic performance and cash flows. (AA Para 15). To ensure that the prepared annual report would meet its purpose the legislative requirements have to be followed and any peculiarities arising from an accounting entity's field of activity should be regulated in the entity's accounting policies and procedures. The determination of an entity's accounting policies and procedures is subject to Paragraph 11 in the Accounting Act. An accounting entity is required to establish accounting policies and procedures which establish the charting of accounts together with a description of the contents of the accounts and which regulate, among other things, the documentation and recording of business transactions, the flow and preservation of source documents, the maintenance of accounting journals and ledgers, the presenting of revenue and expenditure under Income Statement items, physical inventory of assets and liabilities, the accounting policy and presentation 
format used by the accounting entity, the procedure for preparing financial statements, usage of accounting software, and the circumstances relating to the organisation of accounting and the implementation of related internal audit measures.

The objective of the given article is to give an overview about activities required for the preparation of the annual report, alternative accounting policies and accounting estimates, and their presentation in the internal regulations based on companies used as internship bases.

The article is based on the survey carried out at Lääne-Viru College in 2016, which dealt with activities performed in the preparation of the annual report and their presentation in the internal regulations. The survey comprised 94 undertaking companies of different sizes and operating in different fields. The basis for the classification of the undertaking companies participating in the survey was para 3 in the Accounting Act: micro enterprise, small enterprise, medium-sized enterprise, large enterprise. The majority of the respondents were small enterprises - $52(55 \%)$, followed by micro enterprises - 21 (22\%), medium-sized enterprises $-10(11 \%)$, large enterprises $-8(9 \%)$ and municipal authorities $-3(3 \%)$. The main field of activities were stated as agriculture and forestry, construction, merchandising, transport, accommodation, catering, sewing and textile industry, It services, accounting services, real estate management, childcare services, peat extraction, car repair, metal processing, retail of new and second hand vehicles.

\section{Activities performed in the preparation of the annual report}

In accordance with Para 15 in the Accounting Act the following activities have to be performed to prepare the annual report:

- the balances of asset and liability accounts are listed:

- the accordance of the value of the assets and liabilities recorded in the source documents with the basic principles and the Estonian GAAP is assessed;

- $\quad$ adjusting and closing entries are made;

- the financial statements and the notes are prepared.

If the activities required for the preparation of the annual report are detailed enough in the entity's internal regulations and carried out in practice and documented accordingly, it provides confidence that the data shown in the annual report give a true and fair view of the accounting entity's financial position, economic performance and cash flows. While giving a true and fair view of the entity's economic performance book values have to be brought into accordance with the actual situation, i.e. physical counts should be taken.

The requirement for general inventory taking arises from Para 15 in the Accounting Act; however, more specific rules in an entity have to be established by the internal accounting regulations. The current legislation does not regulate the formation of inventory taking committees in the private sector. One of the alternatives is to follow the general rules for state accounting, which states that the management assigns the persons to conduct the annual inventory of inventories, property, plant and equipment and investment property, incl. person(s) responsible for the inventory. Inventory committees related to inventories and property, plant and equipment are comprised of at least two members, neither of whom is the person responsible for the assets subject to inventory (General Rules for State Accounting, Para 50). An entity can also rely on the given act of law in determining its inventory documentation.

Assessing the importance of the different parts of the internal regulations, the respondents considered the inventory taking procedure as the most important part of the internal regulations. When the information flow in an entity is inefficient, the accounting data and the 
actual situation will not be consistent and the information in the statements may be strongly biased.

The survey revealed that the inventory taking procedure was established by the internal accounting regulations and implemented in practice in $83 \%$ of the companies/organisations that participated in the survey. In $15 \%$ of the companies the given part of the regulations needed amendments, and the rest $2 \%$ were lacking internal regulations altogether. A need for amendment was primarily seen in considering the company structure as the basis for the inventory taking procedure in micro and small entities, e.g. forming an inventory taking committee. In small enterprises, especially in micro enterprises with fewer employees it is often impossible to form inventory taking committees at different levels and comprising several members. In that case at least the person responsibly for inventory taking should be determined by the entity's accounting policies and procedures.

Inventory taking procedures were described in medium-sized and large entities and the details were in compliance with the actual procedures and the entity's requirements. However, in all companies of different sizes, the need for working out or improving the inventory taking documentation was recognised.

The practical aspects of inventory taking should be in accordance with the procedures established in the internal accounting regulations, incl. the set documents that have to be prepared during the process. The documents giving evidence of the annual inventory taking are letters of balance confirmation, bank statements, inventory reports and other documents that verify the balances of asset and liability accounts. Most micro entities had prepared the inventory taking documents for the following balance sheet items:

- cash and bank;

- trade receivables;

- prepaid and refundable taxes;

- inventories;

- property, plant and equipment;

- trade payables;

- accrued salaries;

- taxes payable.

Micro entities did not have financial and real estate investments or intangible assets. The largest number of deficiencies in inventory taking documents was found in micro entities, and while checking the documents it was discovered that $28 \%$ of the companies did not have inventory taking documents for some of the items in use. For example, there were no cash taking documents even though the item "cash" existed and cash transactions had taken place. The information received from the accounting data by small enterprises was largely similar to the results of micro enterprises, but in this category more detailed answers were given in the subdivisions of inventories and fixed assets. The main fields of activities for small enterprises were manufacturing or trading, which required inventories and/or fixed assets. Micro enterprises were dominantly service providers (accounting and IT services). In medium-sized and large companies inventory-taking documents had been prepared for the balance sheet items in use and the balances had been checked against the actual situation.

A remarkable finding of the survey is the fact that two activities are often confused - the comparison of balances as part of daily work and inventory taking for the preparation of the annual report. Several questionnaires that had been filled included a remark, such as comparing the current account with the bank statement or comparing the taxes payable with the data by the Tax and Customs Board. This leads to a conclusion that comparison of 
balances was applied in the meaning of taking inventory. However, comparison of balances as part of daily work is not the same as taking inventory. Taking inventory has to be in accordance with the procedures established in the internal accounting regulations.

In accounting and financial reporting established requirements and principles have to be followed. The accounting policies and presentation formats used in accounting shall be in accordance with the requirements and basic principles provided for in Estonian Accounting Act and with accounting principles generally accepted in Estonia or international financial reporting standards approved by the European Commission.

The accounting policies applied by an entity have to be established by the internal accounting regulations (AA Para 11). In addition, where the Guidelines of the Accounting Standards Board provide alternative accounting methods (for FIFO and weighted average cost methods for accounting for inventory), the selected method is disclosed in the notes to the annual financial statements (ASBG 1, Para 65). One of the aims of the survey was to find out if the applied alternative accounting methods were shown in the internal accounting regulations and in the notes to the financial statements in accordance with the rules. The results of the survey are presented in the following table, which also shows the proportions of disclosing accounting policies in enterprises of different sizes.

Table 1. The proportions of disclosing accounting policies by enterprises

\begin{tabular}{|l|c|c|c|c|}
\hline \multicolumn{1}{|c|}{ Accounting policies } & $\begin{array}{c}\text { Micro } \\
\text { undertaking }\end{array}$ & $\begin{array}{c}\text { Small } \\
\text { undertaking }\end{array}$ & $\begin{array}{c}\text { Medium- } \\
\text { sized } \\
\text { undertaking }\end{array}$ & $\begin{array}{c}\text { Large } \\
\text { undertaking }\end{array}$ \\
\hline $\begin{array}{l}\text { are disclosed in the notes to the financial } \\
\text { statements and in the internal accounting } \\
\text { regulations }\end{array}$ & $33 \%$ & $25 \%$ & $48 \%$ & $78 \%$ \\
\hline $\begin{array}{l}\text { are disclosed only in the notes to the financial } \\
\text { statements }\end{array}$ & $24 \%$ & $19 \%$ & $40 \%$ & $22 \%$ \\
\hline $\begin{array}{l}\text { are disclosed only in the internal accounting } \\
\text { regulations }\end{array}$ & $9 \%$ & $6 \%$ & $8 \%$ & $0 \%$ \\
\hline $\begin{array}{l}\text { are disclosed neither in the notes to the financial } \\
\text { statements nor in the internal accounting } \\
\text { regulations }\end{array}$ & & & & \\
\hline
\end{tabular}

Accounting policies were disclosed according to the rules in the majority of larger internship companies; in micro and small enterprises the requirements for disclosing the alternative accounting policies were met in nearly half of the internship companies.

\section{The accounting policies applied in the internship companies}

The Guidelines of the Accounting Standards Board present different accounting methods, whereas each accounting entity will choose and establish the most appropriate accounting methods considering the specifics of their field of activity. While making a choice one should not follow the only accounting method provided by the accounting programme. The effect of different methods has to be carefully considered based on the nature of the business, field of activity and the general economic situation, and a decision has to be made in favour of the method that would give a faithful representation of the entity's financial position and economic performance. The final decision has to be established in the entity's internal regulations.

To assess the compliance of the value of the assets and liabilities shown in the accounting documents with the main principles and the Estonian GAAP, the establishment of the alternative accounting policies in the internal accounting regulations has to be reviewed. The general requirement for the presentation of the accounting policies applied arises from the 
Accounting Act Para 11, and the Guidelines of the Accounting Standards Board provide the following additional requirements:

- The way and frequency of calculating the weighted average cost is established in the entity's internal accounting regulations (ASBG 4 Inventories).

- An accounting entity establishes the depreciation and amortisation methods and rates in their internal accounting regulations, which have to be followed in the depreciation and amortisation of non-current assets as a rule (ASBG 5 Tangible and intangible assets).

The survey revealed that micro and small enterprises mostly use the periodic system and FIFO in accounting for inventory and the period is one calendar month. Medium sized and large enterprises use the perpetual inventory system in most cases. The results of the survey give no evidence of the preferred method - FIFO or weighted average cost - in case of larger enterprises. The one who makes financial decisions has to understand the effect of different methods on the financial statements, the statement of financial position and the statement of profit or loss. Each method has its advantages and disadvantages, which have to be considered while making a choice.

ASBG 5 states that in practice the straight-line depreciation method is most frequently used for tangible assets, but other methods should be considered if they reflect more objectively the distribution of the economic benefit of the asset over its useful life. The aim of the survey was to find out which depreciation method is applied in an entity and what ranges are used for depreciation rates.

Without any exceptions, all respondents representing the micro enterprises that participated in the survey said they used the straight-line method for depreciating fixed assets. In addition, the survey revealed that the depreciation rates used by the given group of respondents ranged from $10 \%$ to $20 \%$.

The straight-line method was also predominantly used by small enterprises, only $4 \%$ use the units-of-output method in accounting for the depreciation of machinery and equipment. The depreciation rates were similar to those of the above-mentioned group of respondents.

The results by medium sized enterprises were slightly different. Even though in most cases the straight-line method was used for the depreciation of fixed assets, $30 \%$ of the respondents used the units-of-output method for depreciating machinery and equipment. The depreciation rates ranged from $10 \%$ to $25 \%$.

In large enterprises only the straight-line method was used. As a result of the survey we can conclude that the depreciation rates remained in the following ranges: buildings from $5 \%$ to $10 \%$, other fixed assets $10 \%$ to $25 \%$.

In conclusion, the survey confirmed that the straight-line method is most often used to depreciate fixed assets. Nevertheless, an entity should use the method that would distribute the acquisition cost over the useful life most accurately based on the revenue generated by the use of the asset in the given accounting period. The choice of the depreciation method for a fixed asset must ensure that expenses are matched to the respective revenues. In addition, we can conclude from the results of the survey that medium sized and large enterprises are likely to set higher depreciation rates for fixed assets, thus making their useful life shorter.

\section{Accounting estimates}

Several financial figures in the financial statements are based on estimates by the management (ASBG 1, Para 74), which can be more realistic than the accounting results. One of the aims of the given survey was to find out how estimates were made in the internship companies. 
In micro and small enterprises a person may be a member of the board of directors and an accountant at the same time, and that may explain the large number of answers, which stated that giving estimates was the responsibility of only the accountant or only the board in these companies. In larger companies the prevailing opinion was that the board of directors, the inventory taking committee and an accountant cooperated in making estimates. An accountant (or an expert) has an advisory role and the board will make the final decision. The results of the survey also revealed the following about the internship companies:

- The individual method was exclusively used in estimating the uncollectible accounts;

- The estimation of receivables as doubtful or bad debts was performed in the process of the inventory taking at the year-end;

- Merchandising companies write their inventories down during the financial year according to the needs, whereas manufacturing and agricultural companies do it rather in the process of the inventory taking at the year-end;

- The historical cost model is likely to be used for real estate investments;

- Making provisions is rather an exception;

- Adjusting entries were made mostly due to the results of taking inventory and periodization;

- No changes in accounting policies were noticed in the internship companies.

\section{Conclusion}

Based on the results of the survey we may conclude that medium-sized and large entities are more likely to be accurate while establishing internal regulations and the related documentation. Micro- and small entities showed more deficiencies in working out their internal regulations as well as in the details to which the given rules were followed. In general, we can still conclude that the regulations necessary for the preparation of the financial statements for the annual report have been established. The investigation of the documents revealed that the activities required to prepare the annual report are performed in companies and this provides a prerequisite for the annual report to give a true and fair view.

\section{Literature}

ASBG 1. General principles in the preparation of the annual report. The Guidelines of the Estonian Accounting Standards Board. http://www.fin.ee/aruandluskorraldus

ASBG 4. Inventories. The Guidelines of the Estonian Accounting Standards Board. http://www.fin.ee/aruandluskorraldus

ASBG 5. Tangible and intangible assets. The Guidelines of the Estonian Accounting Standards Board.

http://www.fin.ee/aruandluskorraldus

The Accounting Act. (20.11.2002), Latest version 01.01.2016.

https://www.riigiteataja.ee/akt/130122015065.

The General Rules for State Accounting. (11.12.2003).

https://www.riigiteataja.ee/akt/121112014020 